\title{
Inoculum Sources to Generate High Mechanical Transmission of Barley yellow mosaic virus
}

\author{
Gilda Jonson*, Yang-Kil Kim, Mi-Jung Kim, Jong-Chul Park, Jong-Nae Hyun and Jung-Gon Kim \\ Honam Agricultural Research Institute, National Institute of Crop Science, RDA, Iksan 570-080, Korea
}

(Received on April 6, 2007; Accepted on May 18, 2007)

\begin{abstract}
Mechanical transmission of barley seedlings with barley yellow mosaic virus (BaYMV) is generally inefficient and is the major constraint for testing cultivar resistance to the virus. To explore mechanical transmission, BaYMV-infected barley plants were grown at different conditions and used as inoculum sources to seedlings of susceptible barley cultivar Baegdong. Extracts prepared from BaYMV-infected Baegdong plants at 47, 53, 74, and 90 days after symptom appearance (DASA) and grown at 10 and $12^{\circ} \mathrm{C}$ gave $10,30,68$ and $76 \%$ infection, respectively on inoculated susceptible barley cv. Baegdong seedlings. While Jinyangbori, another susceptible cultivar obtained $95 \%$ infection rate inoculated with extracts from 90 DASA disease source and grown at $10 / 12^{\circ} \mathrm{C}$. However, low infection rates were obtained when the virus sources were grown in a greenhouse at $15-18^{\circ} \mathrm{C}$. Our results indicate that longer incubation period and lower temperature are required for virus accumulation and stability.
\end{abstract}

Keywords : Bymovirus, Hordeum vulgare, incubation period, transmissible virus

Barley yellow mosaic virus (BaYMV) is one of the most destructive and widespread virus diseases in winter barley, Hordeum vulgare in East Asia and Europe (Kashiwazaki et al., 1989; Adams, 2000). In nature, it co-infeetions with Barley mild mosaic virus (BaMMV) and BaYMV causing enormous yield loss (Huth, 1991). Unfortunately, no control method has found to manage these viruses except for planting resistant cultivars (Adams, 2000; Kanyuka et al., 2003). Both viruses belong to Bymovirus genus and transmitted by the soil-borne fungus, Polymyxa graminis Led. Both BaMMV and BaYMV are mechanically transmissible. BaMMV is readily transmissible, while BaYMV infection rate is often very low (Adams, 2000) discouraging in adapting mechanical inoculation in testing for cultivar resistance. The reason of its difficulty in transmission by mechanical means is not well understood.

\footnotetext{
*Corresponding author.

Phone) +82-63-840-2145, FAX) +82-63-840-2112

E-mail) gilda105@rda.go.kr
}

Virus infection by mechanical means is affected with virus concentration, host susceptibility, stability of the virus, and environmental conditions. Several studies have been done on BaYMV focusing on these factors. Infection rates so far obtained for mechanical transmission of BaYMV was low (below 50\%) (Kashiwazaki, et al., 1989; So et al., 1997) however, if two times of inoculation were applied at 7 days interval, transmission rate was improved (Freidt, 1983). In the case of Wheat spindle striate mosaic virus (WSSMV) another member of Bymovirus genus showed that age of virus source and temperature are essential for virus transmission (Slykhuis, 1974). In the same paper, it was indicated that extracts from tillering stage of plants (approximately 78 days old) when used as inoculum showed significantly higher transmission than extracts from elongated stem and heading stages. Also, growing the source plants at temperature above $15^{\circ} \mathrm{C}$ decreased transmission efficiency. On the other hand, Takanashi et al. (1967) indicated that low infectivity of BaYMV and Wheat yellow mosaic virus (WYMV) by mechanical inoculation was due to the action of polyphenol oxidase. High infection rates were attained in addition of potassium cyanide $(\mathrm{KCN})$ in extraction buffer. While in another study, addition of phenylmethylsulfonyl fluoride (PMSF) was found to increase infectivity in mechanical inoculation of BaYMV-2 (Kuntze et al., 2000).

Consequently, in this paper, in an effort to increase BaYMV transmission by mechanical means, we are reporting effects of age of source plants grown at varying temperatures. Also, effects of enzyme inhibitors such as $\mathrm{KCN}$ and PMSF added in the inoculum were further confirmed.

Korean barley cultivars Baegdong, Jinyangbori, and Hopumbori were used in this study. Field tests showed that Baegdong and Jinyangbori were susceptible (Park et al., 2005) and Hopumbori was resistant (Hyun et al., 2006) to $\mathrm{BaYMV}$. Seedlings were grown at $20-25^{\circ} \mathrm{C}$ in a greenhouse and used for inoculation at the 3-4 leaf stage (approximately 3 weeks from sowing). The virus sources were collected at Haenam, South Korea and tested in ELISA for the presence of BaYMV, BaMMV and soil-borne wheat mosaic virus (SBWMV). Plants infected with BaYMV alone were selected and used as the inoculum sources for 
mechanical inoculation of Baegdong seedlings. Inoculated seedlings were grown in a growth chamber controlled the temperature at 10 and $12^{\circ} \mathrm{C}\left(10 / 12^{\circ} \mathrm{C}\right)$ for 12 hours each under 2000 and 500 lux, respectively.

Inoculum preparation for BaMMV (Jonson et al., 2006) was also applied for BaYMV. In brief, BaYMV infected leaves showing symptoms such as elongated chlorotic streaks were harvested, cut into small pieces, and then ground vigorously using mortar and pestles with 4 times in weight of $0.04 \mathrm{M}$ phosphate buffer $(\mathrm{pH} 7.0)$ containing $0.001 \mathrm{M} \mathrm{KCN}$. Extracts were filtered through doublelayered gauzes, transferred to falcon tubes, and mixed with carborundum ( $600 \mathrm{mesh}$ ) at a rate of $1 \mathrm{mg} / \mathrm{ml}$. The extracts were thoroughly shaken to achieve even distribution of carborundum and inoculated to test seedlings using stick with gauze (SWG) method. SWG method is a modified inoculation technique making used of gauze rolled in a wooden chopstick and was applied by leaf rubbing (Jonson et al., 2006). Inoculated seedlings were maintained in the growth chambers. In each test, 20 seedlings per cultivar were inoculated and experiment was repeated twice. At 45 days after treatments the inoculated seedlings showing typical BaYMV symptoms on the leaves were further tested by RT-PCR using primer pair S13 and S14 designed by Lee et al. (1998). Data were subjected to the analysis of variance using GraphPad Software (San Diego, USA).

The symptoms appeared on inoculated plants at 30 to 45 days after inoculation. In Table 1, extracts from infected Baegdong plants were used as inocula at 47, 63, 74 and 90 days after symptom appearance (DASA). Results from two experiment trials, infection rates of Baegdong seedling varied greatly depending on age of source plants used for the inoculation. Percent seedling infection was higher when older age source plants were used than those younger age source plants. Inoculum sources at 90 DASA gave 7 times higher infection rate than inoculum sources at 47 DASA. Also, extracts prepared from older infected source at 90 DASA was used for inoculating Jinyangbori and Hopumbori

Table 1. Percent seedling infection of cultivar mechanically inoculated with extracts of BaYMV-infected Baegdong plants at $47,53,74$ or 90 days after symptom appearance under $10 / 12^{\circ} \mathrm{C}$

\begin{tabular}{ccc}
\hline \hline $\begin{array}{c}\text { Age of } \\
\text { Disease Source }\end{array}$ & $\begin{array}{c}\text { Number of plants } \\
\text { inoculated/infected }\end{array}$ & $\begin{array}{c}\text { Infection rate } \\
(\%)\end{array}$ \\
\hline 47 & $2 / 40$ & 5.0 \\
53 & $12 / 39$ & 31.0 \\
74 & $26 / 38$ & 68.0 \\
90 & $26 / 34$ & 76.0 \\
\hline
\end{tabular}

${ }^{a}$ Number of days after symptom appearance (DASA). Inoculated seedlings were grown in a growth chamber with temperature controlled at $10^{\circ} \mathrm{C}$ and $12^{\circ} \mathrm{C}\left(10 / 12^{\circ} \mathrm{C}\right)$ for 12 hours each under 2000 and 500 lux, respectively.

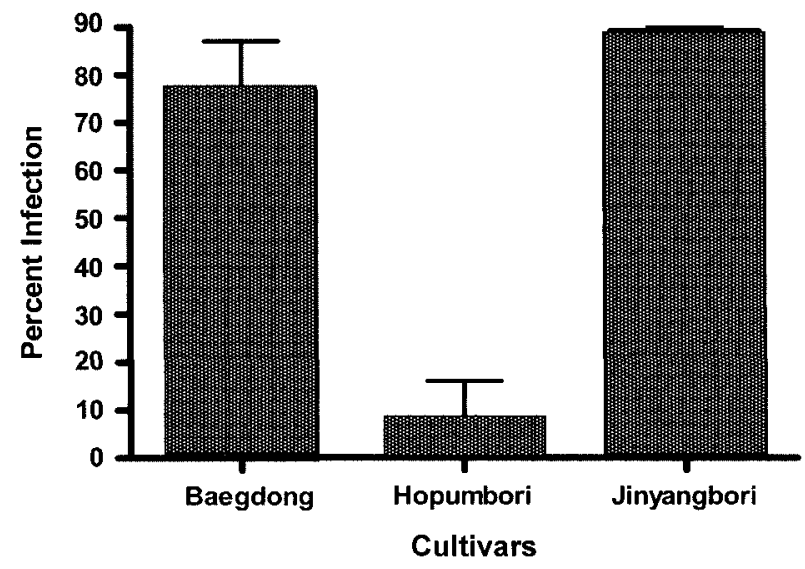

Fig. 1. Percent seedling infection of three barley cultivars which were inoculated with BaYMV-infected barley plants at 90 days after symptom appearance under $10 / 12^{\circ} \mathrm{C}$. Each bar represents the mean and standard deviation (SD) from 2 experiments.

seedlings, a susceptible and resistant of cultivars respectively, to BaYMV in field tests. Results showed that seedling infection rate on Jinyangbori was $95 \%$ which is even surprisingly higher than Baegdong cultivar, while Hopumbori was as low as 6\% (Fig. 1).

To compare the effects of growing temperature, BaYMVinfected plants were grown in the growth chambers under $10 / 12^{\circ} \mathrm{C}$ or in the greenhouse under $15-18^{\circ} \mathrm{C}$, and used as inocula at 90 DASA. The extracts of virus source at 90 DASA grown in the greenhouse under $15-18^{\circ} \mathrm{C}$ gave very low seedling infection on Baegdong (Fig. 2). Again, our results were similar to that of WSSMV that when WSSMVinfected leaves collected in the field at temperature above

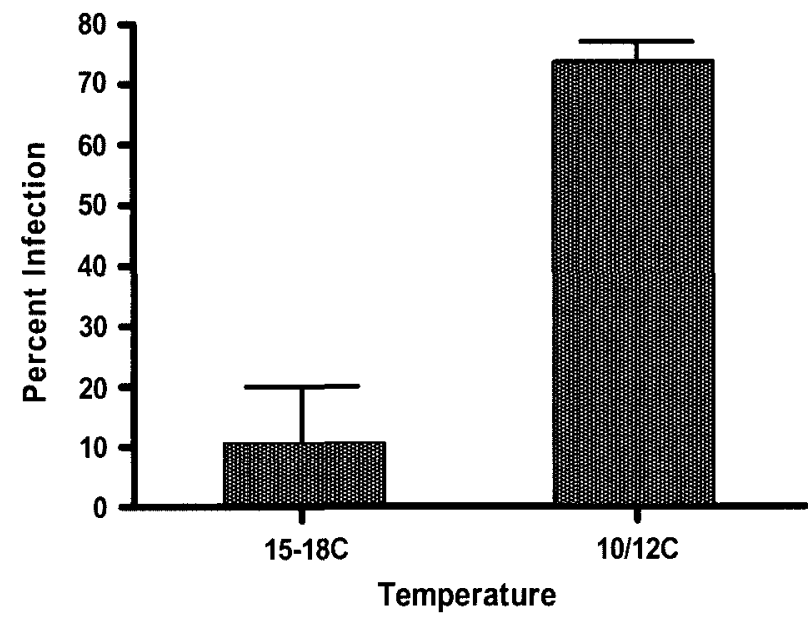

Fig. 2. Percent seedling infection in cultivar Baegdong mechanically inoculated with extracts of BaYMV-infected Baegdong plants at 90 days after symptom appearance grown under $15-18^{\circ} \mathrm{C}$ or $10 / 12^{\circ} \mathrm{C}$. (Note: Temperature in the greenhouse ranged from $15-18^{\circ} \mathrm{C}$ while growth chamber temperature controlled at $10^{\circ} \mathrm{C}$ and $12^{\circ} \mathrm{C}$ for 12 hours each). 
$15^{\circ} \mathrm{C}$ and used as inocula showed a very low or no infection (Slykhuis, 1974). These results demonstrated that WSSMV and BaYMV had similar conditions to be efficiently transmitted: a long incubation at low temperature is necessary for their virus multiplication and virus stability.

To test the effects of protease inhibitors on infection rates, $\mathrm{KCN}$ was replaced with $1 \mathrm{mg} / \mathrm{ml}$ of PMSF. Extracts with no additives served as the control. Application of PMSF in inoculum did not significantly differ from those with $\mathrm{KCN}$ (data not shown).

Our results showed that the conditions required for BaYMV inoculum source to generate high transmission were similar with WSSMV (Slykhuis, 1974). In these experiments, BaYMV source plants at 90 DASA (tillering stage) which were grown at $10 / 12^{\circ} \mathrm{C}$ gave high infections. Indeed, BaYMV also requires low temperature and longer growing period for virus stability and virus accumulation, respectively. Moreover, one time inoculation of extracts containing $\mathrm{KCN}$ using the stick with gauze method generated very high infection on susceptible barley cultivars. Thus, screening for cultivar resistance for BaYMV by mechanical inoculation is now possible with high efficiency and confidence.

\section{Acknowledgement}

The authors are grateful to Dr. Hiroyuki Hibino for critically reviewing the manuscript. This project was supported by Post Doctoral Course Program of HARI, NICS, RDA, Republic of Korea.

\section{References}

Adams, M. J. 2000. Barley yellow mosaic virus. In: Description of Plant Viruses, No. 374. Association of Applied Biologist, UK.

Freidt, W. 1983. Mechanical transmission of soil-borne barley yellow mosaic virus. Phytopath. Z.106:16-22.

Huth, W. 1991. Barley yellow mosaic-a disease in Europe caused by two different viruses. In: Viruses with fungal vectors, ed. by J. I. Cooper and M.J. Asher. pp. 61-70. Association of Applied Biologist, UK.

Hyun, J. N., Han, S. I., Kim, H. T., Kang, J. R., Ko, J. M., Lim, S. G, Kwon, Y. C., Park, D. S., Suh, D. Y., Kim, D. H., Yoon, C. H., Kim, S. T., Suh, S. J. and Kim, S. C. 2006 A new barley cultivar, "Hopum" with high quality and BaYMV resistance. Korean J. Breed. 38:67-68.

Jonson, G., Park, J. C., Noh, T. W., Kim, M. J., Hyun, J. N. and Kim, J. G. 2006. Development of an efficient mechanical inoculation technique to screen barley genotypes for resistance to Barley mild mosaic virus disease and its comparison to natural infection. Plant Pathol. J. 22:348-352.

Kanyuka, K., Ward, E. and Adams, M. J. 2003. Polymyxa graminis and the cereal viruses it transmits: a research challenge. Mol. Plant Pathol. 4:393-406.

Kashiwazaki, S., Ogawa, K., Usugi, T., Omura, T. and Tsuchizaki, T. 1989. Characterization of several strains of barley yellow mosaic virus. Ann. Phytopath. Soc. Japan. 55:16-25.

Lee, J. L. 1998. Analysis and detection of coat protein gene of barley yellow mosaic virus and barley mild mosaic virus by RT-PCR. Korean J. Plant Pathol. 14:314-318.

Takanashi, K., Saito, Y. and Iwata, Y. 1967 Enzyme inhibitors added to the inoculum in mechanical inoculation of soil-borne viruses of wheat and barley. Ann. Phytopathol Jpn. 33:43-47.

Kuntze, L., Bauer, E. and Foroughhi-Wehr, B. 2000. An improved method for the inoculation and detection of BaYMV-2 in winter barley. J. Plant Dis. Prot. 107:310-317.

Park, J. C., Han, O. K., Hyun, J. N., Kim, M. J. and Kim, J. G. 2005. Degree of field reduction by viral disease following by different resistance. Korean J. Crop Sci. 50:178-179.

Slykhuis, J. T. 1974. Factors critical to mechanical transmissibility of wheat spindle streak mosaic virus. Phytopathology 65:582584.

So, I. Y., Lee, K. J., Chon, K. H. and Seo, J. H. 1997. Distribution and screening for barley cultivars resistance to barley yellow mosaic virus and barley mild mosaic virus in Southern Korea. Korean J. Plant Pathol. 13:118-124. 